\title{
Baby oral health promotion centre at a tertiary care hospital in India: A successful model for prevention of early childhood caries
}

\author{
*Indira Mysore Devraj ${ }^{1}$, Narayanappa $D^{1}$, Nandlal Bhojraj ${ }^{1}$ \\ Sri Lanka Journal of Child Health, 2021; 50(1): 56-62
}

\begin{abstract}
Background: Dental caries is the most common chronic disease of the oral cavity. Early childhood caries (ECC) occurs in children less than 71 months of age and can affect the teeth as soon as they erupt. In both developed and developing countries, ECC is a serious public health problem especially for a low socioeconomic group of population. To prevent ECC, children with high risk for caries must be identified at an early age and aggressive strategies must be adopted. In an attempt to achieve a caries-free generation, 'Baby oral health promotion clinic' was established.
\end{abstract}

Objective: To evaluate the effectiveness of establishing a baby oral health promotion clinic in reducing the burden of ECC.

Method: A longitudinal cohort design was adopted. The children visiting the paediatric outpatient department (OPD) for immunization were screened and 150 children were recruited for this study by simple random sampling. All parents in the study were given oral health education through a one to one counselling. To reinforce oral health education, oral health pamphlets were also provided. Intraoral examination was conducted at birth and at 3 monthly intervals for a period of five years. On completion of one year, each child was assessed for caries risk using baby oral health promotion centre (BOHPC) caries risk evaluation form.

Results: Among the 150 recruited subjects, 45 were lost to follow up. A total of 105 children were followed up from birth to five years. Out of 105 subjects who were followed up $37 \%$ had a risk of

\footnotetext{
${ }^{1}$ JSS Academy of Higher Education and Research, Mysore, Karnataka, India

*Correspondence: drindiramd@gmail.com
}

iD. https://orcid.org/0000-0002-2296-1756

(Received on 27 February 2020: Accepted after revision on 10 April 2020)

The authors declare that there are no conflicts of interest

Personal funding was used for the project.

Open Access Article published under the Creative

Commons Attribution CC-BY (c) (i) License developing caries and $1.9 \%$ actually developed ECC suggesting that $98 \%$ of children were cariesfree at the end of 5 year follow-up.

Conclusions: The baby oral health promotion clinic appears to be practical, cost-effective, evidence-based, population-specific, and is successful for the prevention of ECC.

DOI: http://dx.doi.org/10.4038/sljch.v50i1.9404

(Key words: Baby oral health promotion, early childhood caries, infant oral health care)

\section{Introduction}

Dental caries is the most common chronic disease of the oral cavity ${ }^{1}$. Early childhood caries (ECC) occurs in children less than 71 months of age, and can affect the teeth as soon as they erupt. ECC rapidly destroys the deciduous dentition of the child, and when left untreated, leads to pain, acute infection, nutritional insufficiencies, and learning and speech problems ${ }^{2}$.

In both developed and developing countries ECC is a serious public health problem especially for the low socioeconomic group of population ${ }^{3}$. ECC is prevalent across the globe, with around $1-12 \%$ in developed countries. However, in the socially backward groups, prevalence increases to $70 \%$ in developing countries ${ }^{4}$. Prevalence of ECC varied from $2.1 \%$ to $85 \%$ in Sweden and rural Chinese children respectively. According to the literature, highest prevalence of ECC is among 3-4 year old children with low socioeconomic backgrounds. A systematic review on the prevalence of ECC in India reported an overall prevalence of $49.6 \%$; with Sikkim having the lowest prevalence rate of $41.9 \%$ and Andra Pradesh, the highest prevalence rate of $63 \%$. In Karnataka ECC prevalence varied from $15 \%$ to $81.3 \%{ }^{7}$.

Better knowledge about ECC and adoption of preventive measures can reduce the burden of ECC in terms of complications of the disease, its treatment, and quality of life ${ }^{8}$. The responsibility is on child health care professionals, which can be achieved through baby oral health education to caregivers. Most of the oral diseases affecting children are preventable. Prevention can be achieved by early intervention through awareness programmes and oral health examination. 
Preventive oral health educative programmes have shown an increase in parental knowledge?.

Since the children from birth to 5 years are seen more by a paediatrician than a paediatric dentist, introducing oral screening and oral health education as a part of healthy baby check-up right from infancy will have a positive impact on the parents ${ }^{10}$. Children with high risk for caries can be identified at an early age and aggressive strategies can be adopted like anticipatory guidance, behaviour modifications concerning oral hygiene and feeding practices and establishment of a dental home by the time the first tooth erupts. In an attempt to achieve this, 'Baby oral health promotion clinic' was established at the Department of Paediatrics. There are no studies documented in India about the availability of baby oral health promotion centre in the paediatric set up at a tertiary care hospital.

\section{Objective}

To evaluate the effectiveness of establishing the baby oral health promotion centre (BOHPC) in reducing the burden of ECC.

\section{Method}

A longitudinal cohort design was adopted, with the subject being recruited through simple random sampling. The study was conducted at baby oral health promotion clinic in the Department of Paediatrics, tertiary care hospital, Mysore. In a single day, more than 200 children visit the OPD of the Department of Paediatrics, for vaccination. All the children visiting the paediatric OPD for immunization at birth were screened for a period of 6 months and 150 children were recruited for this study based on inclusion criteria by a simple random sampling method. Inclusion criteria were as follows:

- Children born at term ( $\geq 37$ weeks of gestation) and children born preterm (born before 37 completed weeks of gestation).

- Parents of Indian origin and residing in Mysore for at least three generations;

- Subjects belonging to rural population with class II and class III (upper middle and lower middle) socio economic status (Kuppuswamy SES scale 2014).

Ethical issues: Ethical approval for the study was obtained from the Institutional Ethics Committee of JSS Academy of Higher Education and Research, Mysore, Karnataka, India (No. JSS/ ACP/ Ethical/
2012-13). Written informed consent was obtained from parents willing to participate in the study.

All the parents in the study were given oral health education by the paediatric dentist through a one to one counselling. To reinforce the oral health education, oral health pamphlets with information written in the local language were also provided. Intraoral examination was conducted by the paediatric dentist at birth and at 3 monthly intervals for a period of five years. At each visit, oral health education was reinforced and eruption status was evaluated. Caries risk was evaluated using BOHPC caries risk evaluation (BOHPC-CRE) form every year coinciding with the child's birthday up to 5 years (Figure 1).

BOHPC-CRE form adopted from CAMBRA is one of the best caries risk indicator for children. Here caries risk is evaluated by three parameters viz. risk of developing caries, protective factors available to prevent development of caries, and oral examination to evaluate the presence or absence of caries. Caries risk indicators in children $<6$ years old are assessed by parental interview. If the mother has active caries, siblings have caries or a history of caries, the child is born premature, there is a practice of nocturnal bottle feeding or breast feeding after the teeth erupts, if there is in between meal snaking or if there is $>3$ times sugar exposure, such children are categorised as high risk for caries development.

Child with problems like cleft lip/palate, Down syndrome etc. and children who are medically compromised like haematological diseases, respiratory distress etc. are on continuous medication which exposes them to caries risk as medicated syrups have a high sugar content in order to make them palatable to the child. If the child is not exposed to protective factors such as fluoridation, brushing and regular dental visit, this pushes the child towards the high risk category. On examination, if there is non-cavitated or cavitated ECC, then also the child falls into high risk category.

The total risk is quantified based on the balance between caries risk factors and protective factors along with oral examination. If shaded boxes are more than the unshaded boxes then the child is quantified as high risk for caries development and followed up every 3 months giving them health education handouts and self-management goals. 


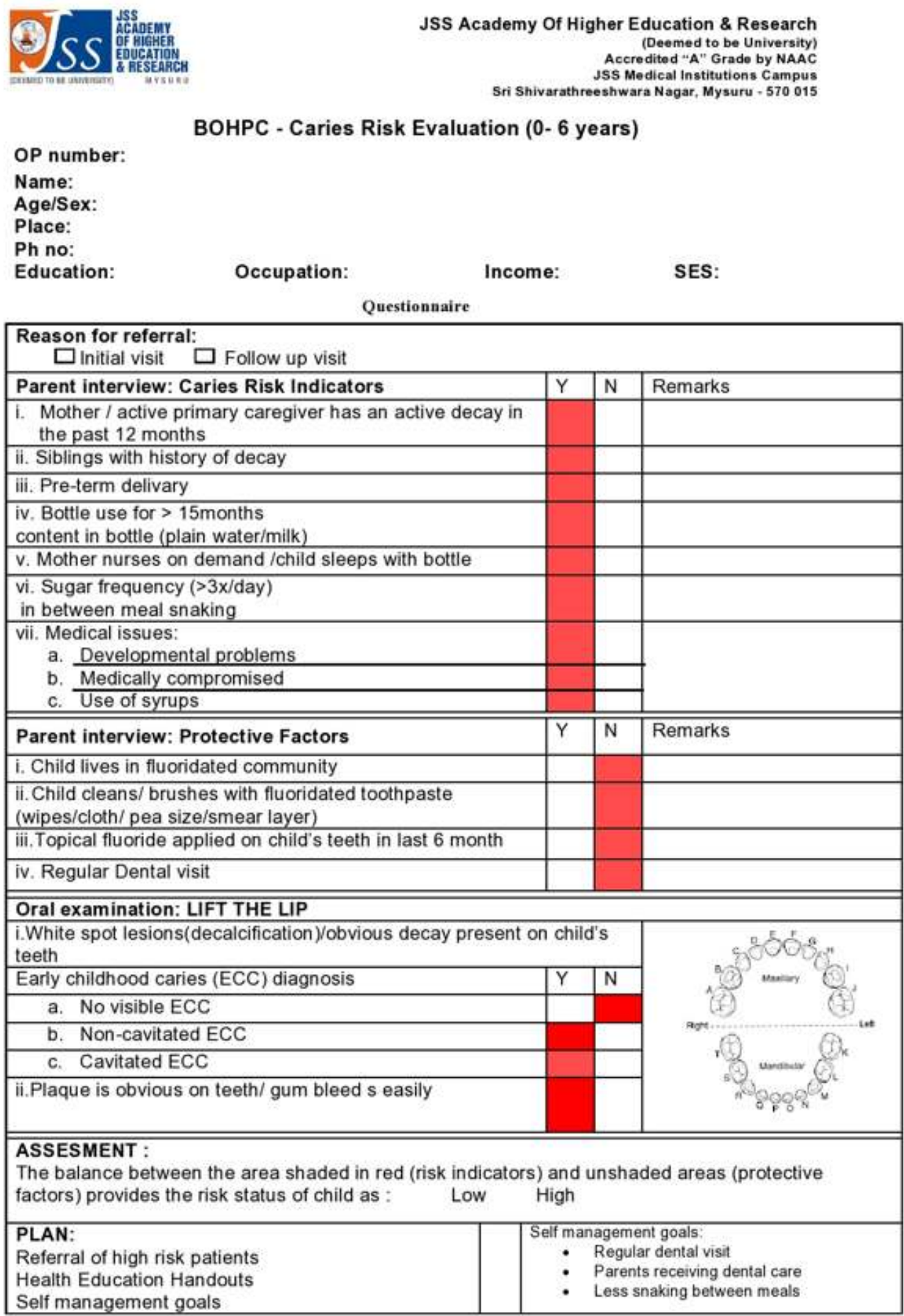

\section{Figure 1: BOHPC caries risk evaluation form}

\section{Results}

This was a longitudinal cohort study conducted over a span of 5 years. Among the 150 recruited subjects, 45 were lost to follow up. A total of 105 children were followed up from birth to five years. The mean age of the mothers of the recruited subjects was 26.1 years. The maternal characteristics are described in Table 1. Mean birth weight, birth length and head circumference were $2.43 \pm 0.34 \mathrm{~kg}, \quad 49.96 \pm 4.66 \mathrm{~cm}$ and $32.32 \pm 2.21 \mathrm{~cm}$ respectively. The child characteristics are described in Table 2. 
Table 1: Maternal characteristics $(n=105)$

\begin{tabular}{|l|c|}
\hline \multicolumn{1}{|c|}{ Characteristic } & n (\%) \\
\hline Mode of delivery & $48(45.7)$ \\
Vaginal & $57(54.3)$ \\
Caesarean & \\
\hline Term of delivery & $51(48.5)$ \\
Preterm & $54(51.5)$ \\
Full term & $63(60.0)$ \\
\hline Parity & $42(40.0)$ \\
First & $73(69.5)$ \\
Second & $32(30.5)$ \\
\hline Socio-economic class & \\
Upper middle & \\
Lower middle &
\end{tabular}

The mean age of eruption of the first primary tooth (mandibular central incisor) was $10.44 \pm 1.89$ months and all the primary teeth erupted by $27.59 \pm 3.38$ months in term children and the mean age of eruption of the first primary tooth (mandibular central incisor) was $11.46 \pm 1.25$ months and all the primary teeth erupted by $30.49 \pm 2.69$ months in pre term children. The corrected age was considered for preterm children. Birth weight and birth length that was below $25^{\text {th }}$ percentile and above $75^{\text {th }}$ percentile showed a delayed eruption of first primary teeth. Complementary feeding introduced after 9 months also showed a delayed eruption of first primary tooth. However socioeconomic status, parity, gender and mode of delivery did not affect the eruption timing (Table 3 ).

Table 2: Child characteristics $(n=105)$

\begin{tabular}{|l|c|}
\hline \multicolumn{1}{|c|}{ Characteristic } & n (\%) \\
\hline Gender & $64(60.9)$ \\
Male & $41(39.1)$ \\
Female & \\
\hline Feeding practice & $82(78.1)$ \\
Exclusively breastfed & $23(21.9)$ \\
Mixed feeding & \\
\hline Introduction of complementary & $55(52.4)$ \\
feeding & $50(47.6)$ \\
6-9 months & \\
$10-12$ months & \\
\hline
\end{tabular}

Table 3: Multivariate analysis of factors affecting eruption timing of first primary tooth

\begin{tabular}{|c|c|c|c|}
\hline Factor & Mean (SD) & B (SE) & p-value \\
\hline $\begin{array}{l}\text { Mode of delivery } \\
\text { Caesarean } \\
\text { Vaginal* }\end{array}$ & $\begin{array}{l}11.16(1.31) \\
11.77(1.13)\end{array}$ & $-0.398(0.450)$ & 0.382 \\
\hline $\begin{array}{l}\text { Term of delivery } \\
\text { Preterm } \\
\text { Full term* }\end{array}$ & $\begin{array}{l}11.16(1.31) \\
10.55(1.87)\end{array}$ & $1.340(0.619)$ & 0.036 \\
\hline $\begin{array}{l}\text { Socio-economic status (SES) } \\
\text { Upper class } \\
\text { Lower class* }\end{array}$ & $\begin{array}{l}11.46(1.25) \\
11.62(1.13)\end{array}$ & $-0.379(0.444)$ & 0.398 \\
\hline $\begin{array}{l}\text { Parity } \\
\text { Second } \\
\text { First* }\end{array}$ & $\begin{array}{l}11.27(1.26) \\
11.60(1.24)\end{array}$ & $0.155(0.457)$ & 0.317 \\
\hline $\begin{array}{l}\text { Gender } \\
\text { Male } \\
\text { Female* }\end{array}$ & $\begin{array}{l}11.42(1.22) \\
11.51(1.33)\end{array}$ & $-0.434(0.424)$ & 0.312 \\
\hline $\begin{array}{l}\text { Birth weight } \\
\text { Extreme } \\
\text { Normal* }^{*}\end{array}$ & $\begin{array}{l}12.50(1.36) \\
11.26(0.66)\end{array}$ & $0.140(0.547)$ & 0.029 \\
\hline $\begin{array}{l}\text { Birth length } \\
\text { Extreme } \\
\text { Normal* } \\
\end{array}$ & $\begin{array}{l}11.47(1.14) \\
10.45(1.29)\end{array}$ & $0.263(0.721)$ & 0.034 \\
\hline $\begin{array}{l}\text { Birth head circumference } \\
\text { Extreme } \\
\text { Normal* }\end{array}$ & $\begin{array}{l}11.68(1.26) \\
11.39(1.26)\end{array}$ & $0.668(0.708)$ & 0.351 \\
\hline $\begin{array}{l}\text { Weight for gestational age }(G A) \\
\text { Small for GA } \\
\text { Appropriate for GA* }\end{array}$ & $\begin{array}{l}12.33(1.06) \\
11.50(1.33)\end{array}$ & $0.328(0.461)$ & 0.050 \\
\hline $\begin{array}{l}\text { Feeding Practice } \\
\text { Combination } \\
\text { Breastfed* }\end{array}$ & $\begin{array}{l}11.40(1.28) \\
11.45(1.25)\end{array}$ & $-0.107(0.523)$ & 0.838 \\
\hline $\begin{array}{l}\text { Complementary feeding } \\
>9 \text { months } \\
\leq 9 \text { months }\end{array}$ & $\begin{array}{l}11.56(1.33) \\
10.12(0.89)\end{array}$ & $0.575(0.540)$ & 0.029 \\
\hline
\end{tabular}

*Reference group; $R$ square $=0.144$ 
On completion of one year, each child was assessed for caries risk using BOHPC caries risk evaluation form. $37 \%(n=39)$ of the subjects showed risk of developing caries. These subjects were more frequently interviewed and oral health education was reinforced. At 3 year follow up each child was reassessed for caries risk. Risk of developing caries reduced to $12 \%(n=13)$. At the end of 5 years, $98 \%$ of children were caries free and $1.9 \%$ actually developed ECC.

\section{Discussion}

ECC has a significant oral health burden on the child population. Hence it requires a strategically planned preventive programme. Infant/baby oral health care is one such programme which targets on the prevention of development of oral diseases in children. For a successful infant oral health programme, early intervention is necessary ${ }^{11,12}$. It helps to provide access to oral care, provide anticipatory guidance and prevent ECC. The best opportunity to provide infant oral health care in India is during the child's vaccination schedule.

A child visits the paediatrician more frequently in the first two years for vaccination purposes. Though they are in a better place to introduce infant oral health care, it's the primary responsibility of a paediatric dentist to provide oral health education and anticipatory guidance to the parents/ caregivers. On an informal interview with mothers it was noted that $>80 \%$ of mothers did not initiate tooth brushing in their wards up to 2 years of age, although the guidelines recommend cleaning of the tooth on eruption of first tooth. In a survey conducted on paediatricians of Mysore city, only $26 \%$ of the paediatrician recommend to clean the tooth as soon as the first tooth erupts and only $48 \%$ referred to the paediatric dentist when they noticed $\mathrm{ECC}^{13}$.

In an attempt to provide comprehensive health care and promote oral health to all the children visiting the hospital, paediatrician and paediatric dentists collaboratively introduced 'Baby oral health promotion clinic' in the Department of Pediatrics, JSS Hospital (tertiary care hospital). In 5 years span 5329 children aged less than 5 years were evaluated for oral health. The goal of this clinic was to provide preventive and interceptive oral health care for infants and young children, implementation of oral hygiene measures right from infancy, assess risk factors for early childhood caries, dietary assessment and provide age appropriate guidance for oro-facial injury prevention

In order to know the effectiveness of this special clinic, 150 children were recruited and followed up for 5 years. More than $98 \%$ of the subjects were caries free at the end of 5 years. Our study cannot be directly compared to other studies as this study has been done in a tertiary hospital where the children belong to mixed group in terms of their socioeconomic status. However, the outcome of oral health education on development of ECC may be compared. Braun et al reported similar finding stating that children less than 3 years old who received oral health promotion programme had reduced $\mathrm{ECC}^{14}$.

Plutzer $\mathrm{K}$, et $a l^{15}$ in their study stated that oral health promotion programme with repeated reinforcement of anticipatory guidance reduced the incidence of S-ECC. However, in this study follow up was done only till 18 months of age; at this age the disease process is at its early stage and many of the subjects who might progress to develop caries were not recorded. In the present study each child was frequently evaluated and oral hygiene methods were reinforced at each visit and followed up to 5 years.

As stated by Lemos LV, et $a l^{16}$ it is absolutely necessary to enrol children below one year of age in oral health programmes in order to promote lifetime good oral health. In this clinic all the parents were trained on feeding practices, introduction of toothpaste and tooth brush, importance of fluoride treatment and injury prevention. The advantage of establishing such a clinic in the paediatric set up is that the child is examined frequently for oral health and the parents are reinforced repeatedly about the importance of primary teeth and maintenance of oral health in children. Also the reinforcement of oral health through paediatricians had a positive impact. Such clinics can be set up in the primary health care centres and anganwadi workers can be trained in this regard so that even the rural population will be benefited from baby oral health promotion.

One limitation of this study is that only a small cohort has been followed up. Further multi centric studies with larger cohorts will be helpful in reducing the burden of ECC.

\section{Conclusions}

The baby oral health promotion clinic appears to be practical, cost-effective, evidence-based, population-specific, and is successful for the prevention of ECC.

\section{References}

1. Glick M, Monteiro da Silva O, Seeberger GK, Xu T, Pucca G, Williams DM, et al. FDI Vision 2020: Shaping the future of oral health. International Dental Journal 2012; 62(6):278-91. 
https://doi.org/10.1111/idj.12009

PMid: 23252585

2. Nunn ME, Braunstein NS, Kaye EK, Dietrich T, Garcia RI, Henshaw MM. Healthy eating index is a predictor of early childhood caries. Journal of Dental Research 2009; 88(4):361-6. https://doi.org/10.1177/002203450933404 3

PMid: 19407158 PMCid: PMC2774803

3. Postma TC, Ayo-Yusuf OA, Van Wyk PJ. Socio-demographic correlates of early childhood caries prevalence and severity in a developing country-South Africa. International Dental Journal 2008; 58(2):91-7.

https://doi.org/10.1111/j.1875595X.2008.t b00182.x

PMid: 18478890

4. Congiu G, Campus G, Lugliè PF. Early childhood caries (ECC) prevalence and background factors: a review. Oral Health and Preventive Dentistry 2014; 12(1):716.

5. Ismail AI, Sohn W. A systematic review of clinical diagnostic criteria of early childhood caries. Journal of Public Health Dentistry 1999; 59(3):171-91. https://doi.org/10.1111/j.17527325.1999.t b03267.x

PMid: 10649590

6. Ramos-Gomez F, Weintraub J, Gansky S, Hoover C, Featherstone J. Bacterial, behavioral and environmental factors associated with early childhood caries. Journal of Clinical Pediatric Dentistry 2003; 26(2):165-73.

https://doi.org/10.17796/jcpd.26.2.t6601j3

618675326

PMid: 11878278

7. Ganesh A, Muthu MS, Mohan A, Kirubakaran R. Prevalence of early childhood caries in India-A systematic review. Indian Journal of Pediatrics 2019; 86(3):276-86.

https://doi.org/10.1007/s12098-018-2793y

PMid: 30284117

8. Tinanoff N, O'sullivan DM. Early childhood caries: overview and recent findings. Pediatric Dentistry 1997; 19:126.
9. Kay E, Locker D. A systematic review of the effectiveness of health promotion aimed at improving oral health. Community Dental Health 1998; 15(3):132-44.

10. Hamilton FA, Davis KE, Blinkhorn AS. An oral health promotion programme for nursing caries. International Journal of Paediatric Dentistry 1999; 9(3):195-200. https://doi.org/10.1046/j.1365263x.1999.0 0132.x

PMid: 10815576

11. Nurko C, Skur P, Brown JP. Caries prevalence of children in an infant oral health educational program at a WIC clinic. Journal of Dentistry for Children 2003; 70(3):231-4.

12. Ramos-Gomez F, Weintraub J, Gansky S, Hoover C, Featherstone J. Bacterial, behavioral and environmental factors associated with early childhood caries. Journal of Clinical Pediatric Dentistry 2003; 26(2):165-73.

https://doi.org/10.17796/jcpd.26.2.t6601j3 618675326

PMid: 11878278

13. Indira MD, Dhull KS, Nandlal B. Knowledge, attitude and practice toward infant oral healthcare among the paediatricians of Mysore: a questionnaire survey. International Journal of Clinical Pediatric Dentistry 2015; 8(3):211. https://doi.org/10.5005/jp-journals-100051315

PMid: 26604540 PMCid: PMC4647042

14. Braun PA, Widmer-Racich K, Sevick C, Starzyk EJ, Mauritson K, Hambidge SJ. Effectiveness on early childhood caries of an oral health promotion program for medical providers. American Journal of Public Health 2017; 107(S1):S97-103. https://doi.org/10.2105/AJPH.2017.30381 7

PMid: 28661802 PMCid: PMC5497886

15. Plutzer K, Spencer AJ. Efficacy of an oral health promotion intervention in the prevention of early childhood caries. Community Dentistry and Oral Epidemiology 2008; 36(4):335-46. https://doi.org/10.1111/j.16000528.2007.0 0414.x

PMid: 19145720 
16. Lemos LV, Myaki SI, Walter LR, Zuanon AC. Oral health promotion in early childhood: age of joining preventive program and behavioural aspects. Einstein (São Paulo) 2014; 12(1):6-10.

https://doi.org/10.1590/S167945082014A

$\mathrm{O} 2895$

PMid: 24728238 PMCid: PMC4898231 